\title{
Perkembangan Anak Ditinjau dari Teori Mature Religion
}

\author{
Windisyah Putra \\ STAIN Gajah Putih Takengon, Aceh \\ Email: bensulingewd@yahoo.co.id
}

\begin{abstract}
Physical development is not necessarily equivalent to spiritual development. Normally, a person who has reached maturity level will have spiritual maturity pattern such as thought maturity, personal maturity, and emotional maturity. Yet, the balance between physical maturity and spiritual maturity sometimes does not run in parallel. One may have grown physically but not spiritually. Religious values need to be established in children since early ages. The religious values mean any deeds relating humans and God or among human beings relationship. Physical development is measured based on chronological age, peak of human physical development which is called maturity. On the other hand, spiritual development is measured based on level of ability and certain ability level achieved by spiritual development which is called maturity.
\end{abstract}

Keywords: physical maturity, mature religion, spiritual development, early childhood

\begin{abstract}
Abstrak
Kedewasaan jasmani belum tentu berkembang setara dengan perkembangan rohani. Umumnya orang dewasa memiliki pola kematangan rohani tetapi dalam beberapa kasus keduanya tidak berkembang secara seimbang. Secara fisik, seseorang mungkin sudah dewasa tetapi secara rohani ia ternyata belum matang, termasuk kematangan keberagamaannya. Nilai-nilai keagamaan perlu ditanamkan kepada anak sejak usia dini. Perkembangan jasmani diukur berdasarkan umur kronologis. Puncak perkembangan jasmani yang dicapai manusia disebut dengan kedewasaan. Perkembangan rohani diukur berdasarkan tingkat kemampuan; pencapaian tingkat abilitas tertentu bagi perkembangan rohani disebut dengan istilah kematangan.
\end{abstract}

Kata kunci: kedewasaan jasmani, kematangan keberagamaan, perkembangan spiritual, anak usia dini 


\section{A. Pendahuluan}

Kemampuan seseorang untuk mengenali atau memahami nilai agama yang terletak pada nilai-nilai luhurnya serta menjadikan nilai-nilai dalam bersikap dan bertingkah laku merupakan ciri dari kematangan beragama, jadi kematangan beragama terlihat dari kemampuan seseorang untuk memahami, menghayati serta mengaplikasikan nilai-nilai luhur agama yang dianutnya dalam kehidupan sehari-hari. Pembentukan sikap, pembinaan moral dan pribadi pada umumnya terjadi melalui pengalaman sejak kecil. Semua pengalaman yang dilalui oleh anak sewaktu kecil, merupakan unsur penting dalam membentuk pribadi. Sikap si anak terhadap agama dibentuk pertama kali di rumah melalui pengalaman yang didapatnya dengan orang tuanya, kemudian disempurnakan atau diperbaiki oleh guru di sekolah, terutama oleh guru yang disayanginya. Kalau kita menginginkan agar agama mempunyai arti pada anak, agama hendaklah disajikan dengan cara yang sesuai dengan anak, yaitu dengan cara yang lebih dekat kepada kehidupannya sehari-hari dan lebih kongkrit. ${ }^{1}$

Usia dini adalah masa dimana segala sesuatu dengan mudah dibentuk dan akan sangat menentukan bagaimana selanjutnya di masa yang akan datang. Hal itulah yang mendasari betapa pentingnya melakukan penelaahan sehingga kita tidak akan melakukan kesalahan-kesalahan fatal dalam membentuk karakter anak. Dapat dikatakan bahwa sikap atau kepribadian seseorang ditentukan oleh pendidikan, bimbingan, pola asuh, pengalaman, dan latihan-latihan yang dilalui pada masa kanak-kanak. Seseorang yang pada masa kecilnya mendapatkan bimbingan, pola asuh, pendidikan, pengalaman dan latihan-latihan hal-hal yang religius, santun dan ringan tangan (suka membantu) terhadap sesama, empatik terhadap kesusahan dan segala masalah persoalan sosial di lingkungan sekitarnya, maka setelah dewasa nanti si anak akan merasakan pentingnya nilai-nilai agama di dalam hidupnya dan kepribadian menuju pada kematangan keagamaan.

Hal ini dapat dimengerti kerena anak sejak usia dini telah melihat dan memperlajari hal-hal yang berada di luar diri mereka. Mereka telah melihat dan mengikuti apa yang dikerjakan dan diajarkan orang dewasa dan orang tua mereka tentang sesuatu yang berhubungan dengan kemaslahatan agama. Dengan demi-

${ }^{1}$ Zakiyah Darajat, Ilmu Jiwa Agama (Jakarta: PT Bulan Bintang, 1987), hlm. 62-63. 
kian, ketaatan dengan ajaran agama merupakan kebiasaan yang menjadi milik mereka yang mereka pelajari dari orang tua maupun guru mereka. ${ }^{2}$

Membimbing kematangan seorang anak dalam beragama haruslah dilakukan dan ditanamkan sejak dini, karena membimbing keagamaan sangat penting untuk menumbuh kembangkan jiwa si anak. Dengan agama dapat mengarahkan perilaku anak ke perilaku yang baik. Dengan agama tentunya diharapkan adanya implikasi dari kematangan beragama anak setelah dewasa nanti. Maka kedewasaan jasmani belum tentu berkembang setara dengan perkembangan rohani. Secara normal memang seorang yang sudah mencapai tingkat kedewasaan akan memiliki pola kematangan rohani seperti kematangan berpikir, kematangan pribadi maupun kematangan emosi. Tetapi perimbangan antara kedewasaan jasmani dan kematangan rohani ini ada kalanya tidak berjalan sejajar. Secara fisik (jasmani) seseorang mungkin sudah dewasa, tetapi secara rohani ia ternyata belum matang.

\section{B. Mature Religion Pada Anak Usia Dini}

Para ahli psikologi dari mazhab psikoanalisis, behavioristis dan humanis sepakat bahwa masa bayi dan masa kanak-kanak awal amatlah penting dan membawa pengaruh yang terbawa terus dalam struktur kepribadian manusia. Bayi yang dilahirkan sudah memiliki beberapa instink, diantaranya instink keagamaan. Belum terlihatnya tindak keagamaan pada diri anak karena beberapa fungsi kejiwaan yang menompang kematangan berfungsinya instink itu belum sempurna. Dengan demikian pendidikan agama perlu diperkenalkan pada anak jauh sebelum usia tujuh tahun. ${ }^{3}$ Artinya jauh sebelum usia tersebut, nilai-nilai keagamaan perlu ditanamkan kepada anak sejak usia dini. Nilai keagamaan itu sendiri bisa berarti perbuatan yang berhubungan antara manusia dengan Tuhan atau hubungan antara sesama manusia.

Kriteria kematangan beragama menurut Walter Houston Clack dalam bukunya "The Psychology of Religion" menjelaskan bahwa Through childhood and adolescence, whether through a

2 Jalaluddin Rakhmat, Psikologi Agama (Jakarta: PT Raja Grafindo Persada, 2005), hlm. 70.

${ }^{3}$ Sugeng Haryadi, Anak Kecil Harus Dilatih Bagaimana Menyayangi Orang Lain, dalam Bulletin PAUD, Dinas P dan K Jawa Tengah, 2003, hlm. 5-6. 
healthy-minded gradual growth or the stresses of conversion, the sensitive religious spirit approaches some sort of resolution which we will now try to describe. This will be a difficult task for several reasons:

1. The process of religious development is never complete.

2. Religious maturity is by no means coincident with physical maturity. indeed most adults can in nowise be said to be religiously mature.

3. Depending on one's concept of religion, religious maturity may be defined in a number of ways, each with its element of validity. Consequently our discussion will be more speculative and arbitrary than objective and precise. yet we have already implied some concept of religious maturity, and it is appropriate that we give more formal consinderation to this. ${ }^{4}$

Manusia mengalami dua macam perkembangan yaitu perkembangan jasmani dan rohani. Perkembangan jasmani diukur berdasarkan umur kronologis, puncak perkembangan jasmani yang dicapai manusia disebut dengan kedewasaan. Sedangkan perkembangan rohani diukur berdasarkan tingkat kemampuan (abilitas), pencapaian tingkat abilitas tertentu bagi perkembangan rohani disebut dengan istilah kematangan (maturity). Oleh karenanya mature religion atau kematangan beragama pada anak adalah sesuatu yang bisa diupayakan karena ia bisa dipelajari dan ditanamkan. Secara bahasa maturation (kemasakan, kematangan) dapat diartikan perkembangan proses mencapai kemasakan/usia masak, atau proses perkembangan yang dianggap berasal dari keturunan, atau merupakan tingkah laku khusus spesies. Maturation adalah istilah yang dipinjam dari biologi, yang menunjuk pada keranuman atas kemasakan sel-sel seks.

\section{Teori Pendekatan Mature Religion pada Anak Usia Dini}

Pernyataan yang timbul adalah apakah yang menjadi sumber pokok yang mendasari timbulnya keinginan untuk mengabdikan diri kepada Tuhan? Atau dengan kata lain, apakah yang menjadi

\footnotetext{
${ }^{4}$ Walter Houston Clack, The Psychology of Religion (New York: The Macmillan Company), hlm. 240.
} 
sumber kejiwaan agama itu? Menurut Robert W. Crapps ${ }^{5}$ untuk memberi jawaban itu timbul beberapa teori antara lain:

1. Teori Monistik $($ Mono $=$ Satu $)$

Teori Monistik berpendapat, bahwa yang menjadi sumber kejiwaan agama adalah satu sumber kejiwaan. Selanjutnya, sumber tunggal manakah yang dimaksud paling dominan sebagai sumber kejiwaan itu? Timbul beberapa pendapat yang dikemukakan oleh:

a. Thomas van Aquino. Sesuai dengan masanya, Thomas Aquino mengemukakan bahwa yang menjadi sumber kejiwaan agama itu, ialah berpikir. Manusia bertuhan karena manusia menggunakan kemampuan berpikirnya. Kehidupan beragama merupakan refleksi dari kehidupan berpikir manusia itu sendiri. Pandangan semacam ini masih tetap mendapat tempatnya, sehingga para filsuf mendewakan rasio sebagai satu-satunya motif yang menjadi sumber agama.

b. Fredrick Hegel. Hampir sama dengan pendapat yang dikemukakan oleh Thomas van Aquino, maka filosof Jerman ini berpendapat, bahwa agama adalah suatu pengetahuan yang sungguh-sungguh benar dan tempat kebenaran abadi. Berdasarkan hal itu agama semata-mata merupakan hal-hal atau persoalan yang berhubungan dengan pikiran.

c. Fredrick Schleimacher. Berlainan pendapat dengan kedua ahli di atas. Maka F. Schleimacher berpendapat bahwa yang menjadi sumber keagamaan itu adalah rasa ketergantungan yang mutlak (sense of depend). Dengan adanya rasa ketergantungan yang mutlak ini manusia merasakan dirinya lemah. Kelemahan ini menyebabkan manusia selalu menggantungkan hidupnya dengan suatu kekuasaan yang berada di luar dirinya. Berdasarkan rasa ketergantungan itulah maka timbul konsep tentang Tuhan. Manusia merasa tak berdaya menghadapi tantangan alam yang selalu dialaminya, maka mereka menggantungkan harapannya kepada suatu kekuasaan yang dianggap mutlak. Rasa ketergantungan yang mutlak ini dapat

${ }^{5}$ Robert W. Crapps, Perkembangan Kepribadian dan Keagamaan (terj. dari buku An introduction to Psychology of Religion. Macon, Georgia: Mercer University Press, 1986), (Yogyakarta: Kanisius, 1994), hlm. 54-62. 
dibuktikan dengan realitas dalam upacara keagamaan dan pengabdian para penganut agama kepada suatu kekuasaan yang mereka namakan Tuhan.

d. Rudolf Otto. Menurut pendapat tokoh ini, sumber kejiwaan agama adalah rasa kagum yang berasal dari the wholly other (yang sama sekali lain). Jika seseorang dipengaruhi rasa kagum terhadap sesuatu yang dianggapnya lain dari yang lain, maka keadaan mental seperti itu diistilahkan oleh R. Otto "numinous". Perasaan semacam itulah yang menurutnya sebagai sumber dari kejiwaan agama pada manusia. Walaupun faktor-faktor lainnya diakui pula oleh $\mathrm{R}$. Otto namun ia berpendapat numinous merupakan sumber yang esensial.

e. Sigmund Frued. Ia berpendapat, unsur kejiwaan yang menjadi sumber kejiwaan agama adalah libido sexual (naluri seksual). Berdasarkan libido ini timbul ide tentang ketuhanan dan upacara keagamaan setelah melalui proses: 1) Oedipoes Complex, yakni mitos Yunani kuno yang beranggapan bahwa karena perasaan cinta kepada ibunya, maka Oedipoes membunuh ayahnya. Kejadian demikian itu berawal dari manusia primitif. Mereka bersekongkol untuk membunuh ayah yang berasal dalam masyarakat promiscuitas. Setelah ayah mereka mati, maka timbullah rasa bersalah (sense of guilt) pada diri anak-anak itu. 2) Father Image (citra bapak) setelah mereka membunuh ayahnya dan dihantui oleh rasa bersalah itu, muncul rasa penyesalan. Perasaan itu menimbulkan ide untuk membuat suatu cara sebagai penebus kesalahan yang mereka lakukan. Keinginan mereka untuk memuja arwah ayah yang telah mereka bunuh itu, karena khawatir akan pembalasan arwah tersebut.

f. William Mac Dougall. Sebagai seorang ahli psikologi insting, ia berpendapat bahwa memang insting khusus sebagai sumber agama tidak ada. Ia berpendapat, sumber kejiwaan agama merupakan kumpulan dari beberapa insting. Menurut Mac Dougall, pada diri manusia terdapat 14 macam insting, maka agama timbul dari dorongan insting secara terintegrasi. Namun demikian teori insting agama ini banyak mendapat bantahan dari para ahli psikologi agama. 


\section{Teori Fakulti (Faculty Theory)}

Teori ini berpendapat bahwa tingkah laku manusia itu tidak bersumber pada suatu faktor yang tunggal tetapi terdiri atas beberapa unsur, antara lain yang dianggap memegang peranan penting adalah: fungsi cipta (reason), rasa (emotion), dan karsa (will). Demikian pula, perbuatan manusia yang bersifat keagamaan dipengaruhi oleh tiga fungsi tersebut:

a. Cipta (reason). Merupakan fungsi intelektual jiwa manusia. Ilmu kalam (Teologi) adalah cerminan adanya pengaruh fungsi intelek ini. Melalui cipta, orang dapat menilai, membandingkan, dan memutuskan suatu tindakan terhadap stimulan tertentu. Perasaan intelek ini dalam agama merupakan suatu kenyataan yang dapat dilihat, terlebih-lebih dalam agama modern, peranan, dan fungsi reason ini sangat menentukan. Dalam lembaga-lembaga keagamaan yang menggunakan ajaran berdasarkan jalan pikiran yang sehat dalam mewujudkan ajaran-ajaran yang masuk akal, fungsi berfikir sangat diutamakan. Malahan ada yang beranggapan bahwa agama yang ajarannya tidak sesuai dengan akal merupakan agama yang kaku dan mati.

b. Rasa (emotion) Suatu tenaga dalam jiwa manusia yang banyak berperan dalam membentuk motivasi dalam corak tingkah laku seseorang. Betapa pun pentingnya fungsi reason, namun jika digunakan secara berlebihan akan menyebabkan ajaran agama itu menjadi dingin. Jadi, yang menjadi objek penyelidikan sekarang pada dasarnya adalah bukan anggapan bahwa pengalaman keagamaan seseorang itu dipengaruhi oleh emosi, melainkan sampai berapa jauhkah peranan emosi itu dalam agama. Sebab, jika secara mutlak emosi yang berperan tunggal dalam agama, maka akan mengurangi nilai agama itu sendiri sebagaimana yang dikemukakan oleh W.H. Clark: upacara keagamaan yang hanya menimbulkan keributan bukanlah agama.

c. Karsa (Will). Merupakan fungsi eksekutif dalam jiwa manusia. Will berfungsi mendorong timbulnya pelaksanaan doktrin serta ajaran agama berdasarkan fungsi kejiwaan. Mungkin saja pengalaman agama seseorang bersifat intelek ataupun emosi, namun jika tanpa adanya peranan will maka agama tersebut belum tentu terwujud sesuai dengan kehendak reason atau emotion. Keadaan yang 
demikian akan menyebabkan penilaian masyarakat terhadap agama tidak akan mendapat tempat yang sewajarnya. Mungkin golongan yang demikian itu melaksanakan ajaran keagamaan secara efisien, tetapi pada dasarnya mereka belum dapat menempatkan ajaran keagamaan pada proporsi yang sebenarnya. Ketiganya berfungsi antara lain: 1) Cipta (reason) berperan untuk menentukan benar atau tidaknya ajaran suatu agama berdasarkan pertimbangan intelek seseorang. 2) Rasa (emotion) menimbulkan sikap batin yang seimbang dan positif dalam menghayati kebenaran ajaran agama. 3) Karsa (will) menimbulkan amalan-amalan atau doktrin keagamaan yang benar dan logis.

Dari kajian di atas ada beberapa pemuka teori fakulti, diantaranya adalah:

a. G.M. Straton. Ia mengemukakan teori "konflik" dengan mengatakan, bahwa yang menjadi sumber kejiwaan agama adalah adanya konflik dalam kejiwaan manusia. Keadaan yang berlawanan seperti: baik-buruk, moral-immoral, kepasipan-keaktifan, rasa rendah diri dan rasa harga diri menimbulkan pertentangan atau konflik dalam diri manusia. Jika konflik itu sudah demikian mencekam manusia dan mempengaruhi kehidupan dan kejiwaannya, maka manusia itu mencari pertolongan kepada suatu kekuasaan yang tertinggi (Tuhan).

b. Zakiyah Darajat. Pada diri manusia itu terdapat kebutuhan pokok. Dia mengemukakan, selain dari kebutuhan jasmani dan kebutuhan rohani, manusia pun mempunyai suatu kebutuhan akan adanya kebutuhan akan keseimbangan dalam kehidupan jiwanya agar tidak mengalami tekanan. Unsur-unsur kebutuhan yang dikemukakan yaitu: 1) Kebutuhan akan rasa kasih sayang adalah kebutuhan yang menyebabkan manusia mendambakan rasa kasih. 2) Kebutuhan akan rasa aman merupakan kebutuhan yang mendorong manusia mengharapkan adanya perlindungan. 3) Kebutuhan akan rasa harga diri adalah kebutuhan yang bersifat individual yang mendorong manusia agar dirinya dihormati dan diakui oleh orang lain. 4) Kebutuhan akan rasa bebas adalah kebutuhan yang menyebabkan seseorang bertindak secara bebas untuk mencapai kondisi dan situasi 
rasa lega. 5) Kebutuhan akan rasa sukses merupakan kebutuhan manusia yang menyebabkan ia mendambakan rasa keinginan untuk dibina dalam bentuk penghargaan terhadap hasil karyanya. 6) Kebutuhan akan rasa ingin tahu (mengenal) adalah kebutuhan yang menyebabkan manusia selalu meneliti dan menyelidiki sesuatu.

c. W.H. Thomas. Melalui teori The Four Wishes-nya ia mengemukakan, bahwa yang menjadi sumber kejiwaan agama adalah empat macam keinginan dasar yang ada dalam jiwa manusia yaitu: 1) Keinginan untuk keselamatan keinginan ini tampak jelas dalam kenyataan manusia untuk memperoleh perlindungan atau penyelamatan dirinya baik berbentuk biologis maupun nonbiologis. 2) Keinginan untuk mendapat penghargaan (recognation). Keinginan ini merupakan dorongan yang menyebabkan manusia mendambakan adanya rasa ingin diharga dan dikenal orang lain. 3) Keinginan untuk ditanggapi (response). Keinginan ini menimbulkan rasa ingin mencintai dan dicinta dalam pergaulan. 4) Keinginan akan pengetahuan atau pengalaman baru (new experience). Keinginan ini menyebabkan manusia mengekpslorasi dirinya untuk mengenal sekelilingnya dan mengembangkan dirinya.

\section{Ciri-ciri Pokok Agama pada Anak Usia Dini}

Menurut Robert W. Crapps ${ }^{6}$ ciri-ciri pokok agama pada masa kanak-kanak dapat muncul kepermukaan diantaranya:

\section{Orientasi Egosentris (Egocentric Orientation)}

Ciri agama pada masa kanak-kanak yang pertama dan paling jelas adalah orientasi egosentris. Ini merupakan hal aneh karena dunia kemana anak dilemparkan pada saat lahir sebagian terbesar menjadi milik orang lain. Pada waktu lahir bayi kecil dikelilingi oleh berbagai kekuatan (bapak, ibu, saudara, saudari) dan kelangsungan hidupnya tergantung dari kekuatan itu. Orientasi egosentris selama masa kanak-kanak dilukiskan dalam penelitian terkenal Jean Piaget tentang bahasa anak antara anak umur 3 dan 7 tahun yaitu merupakan bahasa egosentris "kurang sebagai sarana untuk mengkomunikasikan gagasan dan informasi, dan lebih

\footnotetext{
${ }^{6}$ Robert W. Crapps, Perkembangan Kepribadian ..., hlm. 16-20.
} 
merupakan pernyataan atau penegasan diri dihadapan orang lain.

Agama dengan demikian tidak dapat mengharapkan agama masa kanak-kanak sesuai dengan cita-cita tinggi cinta sesama. Ide anak-anak tentang Tuhan pada awalnya, dibentuk dalam gambaran orang tua dalam kerangka kebutuhan kanakkanak untuk menghadapi lingkungan yang mengancam. Dalam konteks itu "konsep" dan "ide" belumlah sudah terfikirkan masak-masak, dan lebih merupakan peniruan.

2. Kekonkretan Antropomorfis

Di mana kata-kata dan gambaran-gambaran keagamaan diterjemahkan kedalam pengalaman-pengalaman yang sudah dijalani dan biasanya dalam bentuk orang-orang yang sudah dikenal. Pertanyaan anak-anak "bagaimana" dan "mengapa" biasannya mencerminkan usaha mereka untuk menghubungkan penjelasan religius yang abstrak dengan dunia pengalaman mereka yang subyektif dan konkrit. Misalnya, ucapan "Tuhan memberi ganjaran dan menjatuhkan hukuman", dengan cepat dimengerti oleh anak dan dihubungkan dengan pengalaman mereka tentang "orang tua yang memberi hadiah dan hukumam kepada mereka".

Kekonkretan mentalitas anak cenderung menjadi antropomorfis dalam pengambaran mereka tentang Tuhan. Tuhan difikirkan dan secara harafiah digambarkan sebagai bapak atau kakek. Jadi Tuhan memiliki mata untuk melihat, tangan untuk memegang, dan lidah untuk berbicara. Tetapi antropomorfisme yang konkrit itu juga berperan bagi anak dalam mengartikan pengalaman yang dijumpainya. Bapak itu dapat merupakan kebaikan, ancaman, ketakutan dan lain-lain. Antropomorfisme dengan demikian berperan sebagai wahana dan pelestari arti yang bisa hilang karena kemampuan reflektif anak belumlah berkembang.

3. Eksperimentasi, Inisiatif, Spontanitas

Ciri ketiga agama pada masa kanak-kanak tumbuh dari ekperimentasi dengan individualitas, inisiatif, dan spontanitas bersama dengan dunia anak yang cepat meluas melampui lingkaran keluarga, unsur baru berkenaan dengan masalah perpisahan muncul. Umur 4,5 sampai 6 tahun merupakan tahun kritis di mana anak pergi keluar, mengambil inisiatif 
dan menampilkan diri dilingkungan teman-teman sepermainan, dan orang-orang dewasa diluar orang tua juga menyatakan sebagai milik. Masuk ketaman kanak-kanak dan kelas 1 sekolah dasar merupakan petualangan masuk kedalam dunia baru yang menuntut eksperimentasi tambahan dengan identitas.

Bermanfaatlah manakala lembaga-lembaga agama menyediakan model dan meyampaikan bahan-bahan informasi sesuai dengan tingkat dan daya tangkap anak. Tetapi pada umumnya anak memasukan ke dalam pikiran perasaan dan kehendaknya apa yang didengar dan dilihatnya sesuai dengan kemampuannya. Menerima agama masa kanak-kanak dan memberi keleluasaan kepada mereka untuk dengan bebas ikut serta dalam kegiatan umat yang diikuti oleh semua anggota dari segala umur, dapat menjadi cara untuk menyiapkan mereka dalam penjiarahan menuju kedewasaan religius.

\section{E. Proses Pendidikan Agama Bagi Anak Usia Dini}

Perkembangan agama pada masa anak, terjadi melalui pengalaman hidupnya sejak kecil, dalam keluarga, disekolah dan dalam lingkungan masyarakat. Semakin banyak pengalaman yang bersifat agama, (sesuai dengan ajaran agama), akan semakin banyak unsur agama, maka sikap, tindakan, kelakuan dan caranya menghadapi hidup akan sesuai dengan ajaran agama. Menurut Robert W. Crapps ${ }^{7}$ pembinaan pribadi anak, perkembangan agama pada anak, pembiasaan pendidikan pada masa anak dan beberapa hal yang perlu diketahui dan diingat adalah:

1. Pembinaan pribadi anak. Setiap orang tua dan semua guru ingin membina anak agar menjadi orang yang baik, mempunyai kepribadian yang kuat dan sikap mental yang sehat dan ahklak yang terpuji. Semuanya itu dapat diusahakan melalui pendidikan, baik yang formil maupun yang informil. Setiap pengalaman yang dilalui anak, baik melalui penglihatan, pendengaran, maupun perlakuan yang diterimanya akan ikut menentukan pembinaan pribadinya. Orang tua adalah pembina pribadi yang pertama dalam hidup anak.

2. Perkembangan agama pada anak. Perkembangan agama pada anak sangat ditentukan oleh pendidikan dan pengalaman yang

\footnotetext{
${ }^{7}$ Robert W. Crapps, Perkembangan Kepribadian .., hlm. 56-65.
} 
dilaluinya, tetutama pada masa-masa pertumbuhan yang pertama (masa anak) dari umur 0-12 tahun. Seorang anak yang pada masa anak itu tidak mendapat pendidikan agama dan tidak pula mempunyai pengalaman keagamaan, maka ia nanti setelah dewasa akan cenderung pada sikap yang negatif terhadap agama. Seyogianya agama masuk ke dalam pribadi anak bersamaan dengan pertumbuhan pribadinya, yaitu sejak lahir, bahkan lebih dari itu, sejak dalam kandungan. Karena dalam pengamatan ahli jiwa terhadap orang-orang yang mengalami kesukaran kejiwaan, tampak bahwa keadaan dan sikap orang tua ketika si anak di dalam kandungan telah mempunyai pengaruh terhadap pertumbuhan jiwa si anak dikemudian hari. Si anak menerima saja apa yang dikatakan oleh orang tua kepadanya.

3. Pembiasaan pendidikan pada anak. Untuk membina anak agar mempunyai sifat-sifat terpuji, tidaklah mungkin dengan penjelasan pengertian saja, akan tetapi perlu membiasakannya untuk melakukan hal baik yang diharapkan nantinya dia akan mempunyai sifat-sifat tersebut, dan menjauhi sifat tercela. Kebiasaan dan latihan itulah yang membuat dia cenderung kepada melakukan yang baik dan meninggalkan yang kurang baik. Kalau kita ingin agar agama mempunyai arti pada anak, hendaklah disajikan dengan cara yang sesuai dengan anak, yaitu dengan cara yang lebih dekat kepada kehidupannya sehari-hari dan lebih konkrit.

Beberapa hal yang perlu diingat oleh guru. Jangan lupa bahwa guru adalah unsur terpenting dalam pendidikan. Hari depan anak didik tergantung banyak kepada guru. Guru yang pandai, bijaksana dan mempunyai keihklasan dan sikap positif terhadap pekerjaannya, akan membimbing anak didiknya ke arah sikap yang positif terhadap pelajaran yang diberikan kepadanya dan dapat menumbuhkan sikap positif yang diperlukan dalam hidupnya kemudian hari. Sebaliknya guru yang tidak bijaksana dan menunaikan pekerjaannya tidak ikhlas atau didasarkan atas pertimbangan-pertimbangan bukan kepentingan pendidikan.

\section{F. Perkembangan Agama Pada Anak Usia Dini}

Menurut penelitian Ernest Harms perkembangan agama anakanak itu melalui beberapa fase (tingkatan). Dalam bukunya The Development of Religious on Children, ia mengatakan bahwa 
perkembangan agama pada anak-anak itu melalui tiga tingkatan, yaitu:

1. The Fairy Tale Stage (Tingkat Dongeng). Pada tingkatan ini dimulai pada anak yang berusia 3-6 tahun. Pada anak dalam tingkatan ini konsep mengenai Tuhan lebih banyak dipengaruhi oleh fantasi dan emosi. Pada tingkatan ini anak menghayati konsep ketuhanan sesuai dengan tingkat perkembangan intelektualnya. Kehidupan pada masa ini masih banyak dipengaruhi kehidupan fantasi hingga dalam menangapi agama pun anak masih menggunakan konsep fantasi yang diliputi oleh dongeng yang kurang masuk akal. ${ }^{8}$

2. The Realistic Stage (Tingkat Kenyataan). Tingkat ini dimulai sejak anak masuk sekolah dasar hingga usia remaja (endolensense). Pada masa ini, ide-ide ketuhanan anak sudah mencerminkan konsep-konsep yang berdasarkan kepada kenyataan (realitas). Konsep ini timbul melalui lembagalembaga keagamaan dan pengajaran agama dari orang dewasa lainnya. Pada masa ini ide keagamaan anak didasarkan atas dorongan emosional, hingga mereka dapat melahirkan konsep Tuhan yang formalis. Berdasarkan hal itu, maka pada masa ini anak-anak tertarik dan senang pada lembaga keagamaan yang mereka lihat dikelola oleh orang dewasa dalam lingkungan mereka. Segala bentuk tindak (amal) keagamaan mereka ikuti dan pelajari dengan penuh minat. ${ }^{9}$

3. The Individual Stage (Tingkat Individu). Menurut Jalaluddin Rakhmat ${ }^{10}$ pada tingkatan ini anak telah memiliki kepekaan emosi yang paling tinggi sejalan dengan perkembangan usia mereka. Konsep keagamaan yang individualistis ini terbagi atas tiga golongan, yaitu:

a. Konsep ketuhanan yang konvensional dan konservatif dengan depengaruhi sebagian kecil fantasi. Hal tersebut disebabkan oleh pengaruh luar.

b. Konsep ketuhanan yang lebih murni yang dinyatakan dalam pandangan yang bersifat personal (perorangan).

c. Konsep ketuhanan yang bersifat humanistik. Agama telah menjadi etos humanis pada diri mereka dalam menghayati

\footnotetext{
${ }^{8}$ Sugeng Haryadi, Anak Kecil Harus Dilatih..., hlm. 5-6.

9 Jalaluddin Rakhmat, Psikologi Agama..., hlm. 67.

${ }^{10}$ Jalaluddin Rakhmat, Psikologi Agama..., hlm. 67.
} 
ajaran agama. Perubahan ini setiap tingkatan dipengaruhi oleh faktor intern, yaitu perkembangan usia dan faktor ekstern berupa pengaruh luar yang dialaminya.

Ide keagamaan pada anak hampir sepenuhnya ototitarius, maksudnya konsep keagamaan pada diri mereka dipengaruhi oleh faktor dari luar diri mereka. Hal tersebut dapat dimengerti karena anak sejak usia muda telah melihat dan mempelajari hal-hal yang berada diluar diri mereka. Orang tua mempunyai pengaruh terhadap anak sesuai dengan prinsip eksplorasi yang mereka miliki. Bagi mereka sangat mudah untuk menerima ajaran dari orang dewasa, walaupun belum mereka sadari sepenuhnya manfaat ajaran tersebut. Berdasarkan hal itu, Menurut Jalaluddin Rakhmat $^{11}$ dalam bukunya psikologi agama, maka bentuk dan sifat agama pada diri anak dapat dibagi atas:

1. Unreflective (tidak mendalam). Dalam penelitian Machion tentang sejumlah konsep ketuhanan pada diri anak, 73\% mereka menganggap Tuhan itu bersifat seperti manusia. Anggapan mereka terhadap ajaran agama dapat saja mereka terima dengan tanpa kritik. Kebenaran yang mereka terima tidak begitu mendalam, sehingga cukup sekadarnya saja dan mereka sudah merasa puas dengan keterangan yang kadangkadang kurang masuk akal.

2. Egosentris. Anak memiliki kesadaran akan diri sendiri sejak tahun pertama usia perkembangannya dan akan berkembang sejalan dengan pertambahan pengalamannya. Apabila kesadaran akan diri itu mulai subur pada anak, maka akan tumbuh keraguan pada rasa egonya.

3. Anthromorphis. Pada umumnya, konsep mengenai keTuhanan pada anak berasal dari hasil pengalamannya dikala ia berhubungan dengan orang lain. Tapi semua kenyataan bahwa konsep ketuhanan mereka tampak jelas mengambarkan aspekaspek kemanusiaan.

4. Verbalis dan Ritualis. Kehidupan agama pada anak sebagian besar tumbuh mula-mula sejak secara verbal (ucapan). Mereka menghafal secara verbal kalimat-kalimat keagamaan dan selain itu pula dari amaliyah yang mereka laksanakan berdasarkan pengalaman menurut tuntunan yang diajarkan kepada meraka. Latihan-latihan yang bersifat ferbalis dan

${ }^{11}$ Jalaluddin Rakhmat, Psikologi Agama..., hlm. 70-73. 
upacara keagamaan yang bersifat ritualis (praktik-praktik) merupakan hal yang berarti dan merupakan salah satu ciri tingkat perkembangan agama pada anak-anak.

5. Imitative. Mereka melaksanakan karena hasil melihat perbuatan dilingkungan, baik berupa pembiasaan ataupun pengajaran yang intensif. Para ahli jiwa menganggap bahwa dalam segala hal anak merupakan peniru yang ulung. Sifat peniru ini merupakan modal yang positif dalam pendidikan keagamaan pada anak. Menurut penelitian Gillesphy dan Young terhadap sejumlah mahasiswa disalah satu perguruan tinggi menunjukan bahwa anak yang tidak mendapat pendidikan agama dalam keluarga tidak akan dapat diharapkan menjadi pemilik kematangan agama yang kekal.

\section{G. Mature Religion Dilihat Dalam Perspektif Islam}

Sebagai makluk ciptaanTuhan sebenarnya potensi agama sudah ada pada setiap manusia sejak ia dilahirkan. Potensi ini merupakan dorongan untuk mengabdi pada sang pencipta. Dalam terminologi Islam, dorongan ini dikenal dengan hidayat al diniyat (baca: hidayatudiniyah), berupa benih-benih keberagamaan yang dianugerahkan kepada manusia. Dengan adanya potensi bawaan ini manusia pada hakikatnya merupakan makluk beragama. Konsep ajaran Islam menegaskan bahwa pada hakikatnya penciptaan jin dan manusia adalah untuk menjadi pengabdi yang setia kepada penciptannya (Q.S aż-Żariyāt/51:56).

Dalam Al-Quran, sebenarnya sebelum manusia dilahirkan telah mengadakan "transaksi" atau "perjanjian" dengan yaitu mengakui keesaan Tuhan, dalam Q.S al-A'rāf : 172 Allah berfirman: dan (ingatlah), ketika Tuhanmu mengeluarkan keturunan anak-anak Adam dari sulbi mereka dan Allah mengambil kesaksian terhadap jiwa mereka (seraya berfirman): "Bukankah aku ini Tuhanmu?" mereka menjawab: "Betul (Engkau Tuhan kami), Kami menjadi saksi". (kami lakukan yang demikian itu) agar di hari kiamat kamu tidak mengatakan: "Sesungguhnya Kami (Bani Adam) adalah orang-orang yang lengah terhadap ini (keesaan Tuhan)".

Apabila kita memperhatikan ayat ini, memberi gambaran bahwa setiap anak yang lahir telah membawa "potensi keimanan" terhadap Allah atau disebut dengan "tauhid". Sedangkan potensi 
bawaan yang lain misalnya potensi fisik dan intelegensi atau kecerdasan akal dengan segala kemungkinan dan keterbatasannya. Menurut Abdullah Nashih Ulwan (2007: 142) nilai keberagaman dapat ditumbuhkan dengan metode pendidikan terhadap anak, yaitu sebagai berikut:

1. Pendidikan dengan keteladanan. Keteladanan dalam pendidikan merupakan metode yang berpengaruh dan terbukti paling berhasil dalam mempersiapkan dan membentuk aspek moral, spiritual, dan etos sosial anak. Mengingat pendidik adalah seorang figur terbaik dalam pandangan anak, pendidik dapat memberikan nilai-nilai keteladan seperti tindak tanduk dan sopan santun, secara tidak langsung akan ditiru oleh mereka. Bahkan bentuk perkataan, perbuatan, dan tindak tanduknya akan senantiasa tertanam dalam kepribadian anak.

2. Pendidikan dengan adat kebiasaan. Termasuk masalah yang sudah merupakan ketetapan dalam syariat Islam, bahwa anak sejak lahir telah diciptakan dengan fitrah tauhid yang murni, agama yang benar, dan iman kepada Allah. Sesuai dengan firman Allah yang artinya Allah yang telah menciptakan manusia menurut fitrah itu. Tidak ada perubahan pada fitrah Allah (itulah) agama yang lurus, tetapi kebanyakan manusia tidak mengetahui (Q.S. ar-Rūm/30:30). Sesuai pula dengan sabda Rasulullah saw., yang diriwayatkan oleh Bukhari yaitu "setiap anak dilahirkan dalam keadaan fitrah".

3. Pendidikan dengan nasehat. Metode pendidikan yang cukup berhasil dalam pembentukan akidah anak dan mempersiapkannya baik secara moral, emosional maupun sosial, adalah pendidikan anak dengan petuah dan memberikan kepadanya nasehat-nasehat. Karena nasehat dan petuah memiliki pengaruh yang cukup besar dalam membuka mata anak-anak kesadaran akan hakikat sesuatu, mendorong mereka menuju harkat dan martabat yang luhur, menghiasinya dengan akhlak yang mulia, serta membekalinya dengan prinsip-prisnsip Islam. Di bawah ini terdapat dalam Quran surat Luqman ayat 13 yang artinya: "dan (ingatlah) ketika Luqman berkata kepada anaknya, diwaktu ia memberi pelajaran kepadanya".

4. Pendidikan dengan memberikan perhatian atau pengawasan. Pendidikan dengan perhatian adalah senantiasa mencurahkan perhatian penuh dan mengikuti perkembangan aspek akidah dan moral anak, mengawasi dan memperhatikan kesiapan 
mental dan sosial, disamping selalu bertanya tentang situasi pendidikan jasmani dan kemampuan ilmiahnya. Islam, dengan keuniversalan prinsip dan peraturannya yang abadi, memerintahkan kepada bapak, ibu, dan pendidik untuk memperhatikan dan senantiasa mengikuti serta mengawasi anak-anaknya dalam segala segi kehidupan dan pendidikan yang universal.

5. Pendidikan dengan memberikan hukuman. Syariat Islam yang lurus dan adil serta prinsip-prinsipnya yang universal, sungguh memiliki peran dalam melindungi kebutuhankebutuhan primer yang tidak bisa dilepaskan dari kehidupan umat manusia. Hukuman bagaimanapun bentuknya, baik hukuman qiṣas maupun ta'zir, semuaanya itu adalah cara yang tegas dan tepat untuk memperbaiki umat dan mengukuhkan pilar-pilar keamanan serta ketentraman dalam kehidupan umat manusia. Di bawah ini metode yang dipakai Islam dalam upaya memberikan hukuman kepada anak: 1) Lemah lembut dan kasih sayang adalah dasar pembenahan anak; 2) Menjaga tabiat anak yang salah dalam menggunakan hukuman. Anak-anak, dilihat dari segi kecerdasannya berbeda, baik karakter maupun pemberian tanggapannya. Juga berbeda dari segi pembawaan, tergantung pada perbandingan masing-masing.

\section{H. Kesimpulan}

Kemampuan seseorang untuk mengenali atau memahami nilai agama yang terletak pada nilai-nilai luhurnya serta menjadikan nilai-nilai dalam bersikap dan bertingkah laku merupakan ciri dari kematangan beragama, jadi kematangan beragama terlihat dari kemampuan seseorang untuk memahami, menghayati serta mengaplikasikan nilai-nilai luhur agama yang dianutnya dalam kehidupan sehari-hari.

Usia anak-anak adalah masa dimana segala sesuatu dengan mudah dibentuk dan akan sangat menentukan bagaimana selanjutnya dimasa yang akan datang. Hal itulah yang mendasari betapa pentingnya penelaahan dilakukan sehingga kita tidak akan melakukan kesalahan-kesalahan fatal dalam membentuk karakter anak. Dapat dikatakan bahwa sikap atau kepribadian seseorang ditentukan oleh pendidikan, bimbingan, pola asuh, pengalaman, dan latihan-latihan yang dilalui pada masa kanak-kanak. Seseorang yang 
pada masa kecilnya mendapatkan bimbingan, pola asuh, pendidikan, pengalaman dan latihan-latihan hal-hal yang religius, santun dan ringan tangan (suka membantu) terhadap sesama, empatik terhadap kesusahan dan segala masalah persoalan sosial di lingkungan sekitarnya, maka setelah dewasa nanti akan merasakan pentingnya nilai-nilai agama di dalam hidupnya dan kepribadian menuju pada kematangan keagamaan.

\section{Kepustakaan}

Crapps W. Robert. 1994. Perkembangan Kepribadian dan Keagamaan (terj. An introduction to Psychology of Religion. Macon, Georgia: Mercer University Press, 1986), Yogyakarta: Kanisius.

Darajat, Zakiyah. 1987. Ilmu Jiwa Agama Jakarta: PT Bulan Bintang,.

Rahmat, Jalaluddin. 2005. Psikologi Agama, Jakarta: PT Raja Grafindo Persada.

Haryadi, Sugeng. 2003. Anak Kecil Harus Dilatih Bagaimana Menyayangi Orang Lain, dalam Bulletin PAUD, Dinas P dan K Jawa Tengah.

Houston Clack Walter. The Psychology of Religion, New York: The Macmillan Company.

Nashih Ulwan, Abdullah. 2007. Pendidikan Anak Dalam Islam (terj. Jamaluddin Miri, dari judul aslinya "Tarbiyatul Aulad fil Isläm'). Jakarta: Pustaka Amani.

http://kakadi.info. diunduh pada tanggal 10 Januari 2012. 
